\title{
Realizes the Arts Learning Society in Nonformal Education Institutions with Internet Literacy: Study in Qaryah Thayyibah, Salatiga
}

\author{
A O Shabrina ${ }^{1}$, Mulyanto $^{2}$, Harini $^{3}$ \\ ${ }^{1,2}$ Magister Student of Art Education, Universitas Sebelas Maret, Surakarta, Indonesia \\ ${ }^{3}$ Faculty of Teacher Training and Education, Universitas Sebelas Maret, Indonesia \\ annisaoktaa@gmail.com
}

\begin{abstract}
Internet literacy helped to form an art learning society at Pusat Kegiatan Belajar Masyarakat (PKBM) Qaryah Thayyibah. The intended internet literacy includes the ability of students to sort unlimited information from the internet that is in accordance with their learning needs. The learning society in question includes organizing art forums in PKBM Qaryah Thayyibah, namely in the form of forum members, study schedules, ideas and targets, products and things that affect the process of learning art. Qualitative descriptive research data is collected by interviews (art forum and companion participants), observation (learning activities and learning environment) and document analysis (data from art forum members). The results of the study were that art forum participants were students with a diversity of potential, gender differences, differences in age and level of education and differences in learning needs to get equal opportunities in the learning process. Art forum participants actively use the internet, which is looking for literature on the material needed. The art forum in its implementation provides a flexible learning space for the development of students potential in the arts, so that everything related to the learning process of art forums supports the creation of active and independent art learning society.
\end{abstract}

Keywords: Learning Society, Art Forum, Nonformal Education, Internet

\section{INTRODUCTION}

Art is a field of science which scope is broad, can touch various fields of science, and is closely related to life. Art in formal education institutions still lacks attention. Art generally in formal education institutions only gets 1 to 2 hours of study each week. Formal education are limited by various factors, such as age, students, place, and time [1]. The limitations in the implementation of education in formal institutions make non-formal education institutions an alternative in an effort to obtain education that suits their needs. Non-formal education is an 
educational path that is organized outside the formal education system in an organized manner to serve certain student goals and learn in certain ways [2].

PKBM Qaryah Thayyibah is one of the non-formal educational institutions promoted by the Kalibening village of Salatiga as one of the alternative education as well as equalization education institutions. PKBM Qaryah Thayyibah in its implementation tried to provide flexibility of learning for students, especially in the field of the arts, both visual art and music. PKBM Qaryah Thayyibah is committed to provide the widest possible space for students in learning. Students are free to set learning goals, study materials, learning resources and media to learn art. In addition, students with artistic tendencies can hold joint evaluations of the achievements that have been obtained and the obstacles that are passed in the learning process.

Previous research regarding the role of the formation of learning communities basically emphasized the eradication of illiteracy, the universalization of basic education and continuing education [3]. Then new research emphasized the role of PKBM in facilitating lifelong education that emphasized the learning needs of students and also provided educational programs as needed [1]. Both of these studies can be used as references, with such a timeframe, the formation of learning communities in the form of non-formal institutions no longer focuses on eradicating illiteracy but rather to provide students with alternatives in learning. This research focuses more on the implementation of PKBM with the learning culture adopted as which is a joint effort to facilitate the diversity of potentials and interests, especially in the arts.

The formation of an art learning society certainly requires learning resources that are suitable with the objectives of the program and can facilitate the diversity of students potential. The internet is one of the most relevant learning resources. Through the internet, art forum participants can search for material and also the source of ideas needed in the learning process. The internet that holds information is not limited to its use requires wisdom so that the art information sought can be absorbed properly and according to needs. The wisdom of using the internet is a way to maximize the benefits of the internet and minimize negative information from the internet

Based on the learning background, educational institutions created by the society and for the benefit of society are an interesting thing to learn. So the aim of this study is to describe how internet literacy in shaping the art learning society in PKBM Qaryah Thayyibah. Internet literacy in question includes the ability of students to sort infinite information from the internet that fits their learning needs. The learning community in question includes organizing art forums in PKBM Qaryah Thayyibah, forum members, study schedules, ideas and targets and things things that affect the process of learning arts.

\section{METHOD}

This qualitative descriptive study was conducted to describe internet literacy in shaping the art learning society in PKBM Qaryah Thayyibah, Kalibening Village, Salatiga City, Central Java. The study was conducted in March to June 2018. Data collection techniques with interviews (informants in form of companions and art forum participants), observation (learning environment and learning process), documents and archives these are studying art learning with data in PKBM and books. The data analysis technique uses three activity lines that occur simultaneously and continuously so that the data is saturated [4]. The three lines are data condentation, data display and data conclution. Condensation data includes transcripts of interview data, observations and documents / archives. Data presentation is in the form of in- 
depth analysis of data based on understanding and drawing conclusions about data obtained based on understanding.

\section{RESULTS AND DISCUSSION}

PKBM Qaryah Thayyibah has visual art forums (Handycraft forums, Sanggar and Films) and Music forums. Members of the art forum, as many as 22 students, ranging in age from 1322 years, come from sharing cities in Indonesia such as Jakarta, Cirebon, Palembang, Salatiga, Semarang, Pekalongan, Jombang and also Ambarawa. Students come from middle-class economy up to the top, with a background of parents as farmers, private employees, teachers and lecturers. Students at PKBM Qaryah Thayyibah are free to join art forums according to their interests and can participate in more than one art forum. The forum meeting schedule is one week twice. The Sanggar forum is on Thursday and Friday, the Music forum every Friday and Saturday, the Film forum every Tuesday and Wednesday and the Handicraft forum every Wednesday and Thursday. The art forum meeting activities discuss the idea and targets, the development of learning, the obstacles and achievements that have been achieved and also learn about the art materials that want to be studied together. The art forum participants were also to participate in joint activities in the form of Tawashi (sharing knowledge), ceremonies, Gelar Karya (work titles), class meetings, and Hari Kesehatan (Health Day). In addition to joint activities, forum participants were given flexibility in the process of learning art, not limited to time or material. The sourches of art forum participants is mentor, alumni and internet. The internet is a learning resource that is most often used by art forum participants

\subsection{Internet as a Source of Learning Art}

The internet allows an efficient and effective learning process. "The Internet is a collection of information on each user, many people are highly dependent on the Internet, because the Internet has many advantages that can simplify a lot of work, the internet is helpful for effectiveness and efficiency " [5]. The internet that contains a lot of information in its use indirectly requires sensitive users and understands the meaning of the information contained. This sensitivity in understanding information on the internet needs to be honed so as to maximize the absorption of information.

The use of the internet as a source of learning is very important for art forum participants, this is because through the internet art forum participants can simultaneously learn material and also practice. The material on the internet is diverse, can facilitate students with diverse artistic tendencies in the form of music, film, handicrafts, comics, visual communication design, fashion design, painting, and others. Art forum participants also use the internet as a source of ideas with the availability of information about events that occur around them even in the world.

The tendency to learn through the internet is facilitated by the presence of computer rooms with internet access. Appropriate use of the internet is the main thing that needs to be considered by art forum participants. Art forum participants must understand that the internet is a conceptual and relevant tool for diverse learning needs. The internet in its use also requires users to increase adaptability so that directly art forum participants can avoid negative information from the internet. Lack of skills in accessing the internet will limit the information obtained. So it is important for art forum participants to understand, evaluate, sort out the weaknesses and strengths of the internet. 
Art forum participants who have diverse potentials and interests make use of the information on the internet as a learning resource as well as the source of ideas for the creation of works. Art forum participants can download and print certain art material, follow the stages of working on Youtube and find learning resources in the form of mentors using social media. The maximum use of the internet will maximize the products produced by art forum participants. In addition, the internet can help the ongoing learning process so that art forum participants can fulfill their learning needs.

\subsection{Society Learns Art as Lifelong Education}

The art learning society is a continuously intensified effort and is the main goal of the establishment of art forums in PKBM Qaryah Thayyibah. Students with a diversity of potential, gender differences, differences in age and level of education and differences in learning needs get equal opportunities in the learning process, especially in the arts. Art forum participants are free to use their time in the learning process. There are several art forums, namely Sanggar, Handicraft, Film and Music forums. The process of learning art involves things that are around art forum participants such as friends, companions, mentors, alumni, community environment and learning facilities. Freedom to use all resources in PKBM Qaryah Thayyibah in accordance with the aim of organizing non-formal education institutions that seek to provide alternatives in learning, namely facilitating certain students with certain learning methods. This means that PKBM Qaryah Thayyibah removes all the restrictions that are usually applied in formal education institutions as an effort to maximize the potential of students.

The involvement of all components around the participants of the art forum is very important in their role in assisting the achievement of learning arts. The contribution of input components can be a motivation and maximize the learning process that is passed by art forum participants. Motivation in learning activities is a person's motivation or willingness to carry out learning activities so that learning achievement can be achieved optimally [6]. Motivation can be formed with advice, supervision and care of all parties to the development of learning forum art participants. Motivation will generate energy that can help students get excited in the learning process. Motivation is an energy that comes from within that generates, directs and gives the power to remain in that direction to the individual in achieving a goal [7]. Learning motivation can maintain the continuity of the art learning process. Mutually encouraging activities in art forums are the key to the formation of active and independent art learning society.

Art forums are created as a forum for each student's potential and talent whose purpose is to build a personal learner. The freedom to create learning targets and ideas in art forums was conceived as an important part of training art forum participants in meeting their learning needs. Activities to create ideas and targets can be active, independent, responsible, productive, work hard and have confidence in the ideas and results of learning from art forum participants. As a learning person, forum participants are active in the process of learning activities and also actively play a role in their study groups in forums and classes.

An idea-making activity is an effort to train the awareness of art forum participants on events and phenomena that occur around them. Ideas not limited to the arts, may be general (political, legal, health, environmental, agricultural, etc.). Sensitivity is encouraged as a means of developing empathy so that in the art learning process art forum participants can develop their abilities by paying attention to the environment and the surrounding community. The existence of an art forum that is close to the community can also add to the experience of art 
forum participants while increasing awareness of learning arts. The community environment has a big influence on children's learning processes. All things and events around the child have a direct influence on the formation and development of children [8]. Environmental involvement is important in building the social and emotional potential framework of art forum participants. People's participation in educational activities is an important factor in social and emotional development [9].

Participants the art forum also make learning targets in the arts they are studying. Art forum participants are given the freedom to choose learning media, learning resources, mentors and also what things are needed in meeting their targets. It is this process of achieving individual targets which then trains art forum participants in building learning frameworks, understanding needs, namely actively and independently in the process of fulfilling learning needs. The target group is arranged based on decisions with members of the art forum, the process of achievement by working together, sharing work and motivating each other. The target group trains art forum participants to respect the opinions of others as well as mutual cooperation.

All Qaryah Tahyyibah members both members of the art forum and other forums each play a role in supporting each other's learning activities. The facilitator is responsible for overseeing the learning process that takes place at PKBM Qaryah Thayyibah. Active involvement by friends and companions greatly influences the process of learning art, helping to solve problems and achieve targets that have been made. In addition, the involvement of parents in terms of controlling the development of the learning of art forum participants is very important as an effort to give attention to the learning process of students. The involvement of parents of students in children's education is seen through mutual support between the assistance of children at home and educational institutions.

The process of learning art that is conditioned as such must certainly be evaluated. The participants of the art forum and also the companion together evaluate the results obtained based on the targets made. An important evaluation is carried out as an effort to monitor the enthusiasm of learning art forum participants as well as a forum for all learning citizens to find solutions to problems in meeting targets and also a means of appreciation for targets that have been achieved.

The liberating learning process makes each student with a diversity of potential tendencies in the art to make the learning outcomes produced also diverse. The products produced in the Sanggar forum can be in the form of comics, paintings, drawings and poster designs. Handycraft forums with waste management, make selling crafts that are powerless. Film forums with expertise in guitar instruments, drums, singing and making musical instruments. The Film forum is in the form of short films, social films, advertisements and others. Diverse learning outcomes are expected to present the ability of art forum participants who in the future are expected to be able to shape art forum participants in their lives. That is, expertise in the field of art acquired in the learning process can be used as a livelihood. The attitude and personality of the learners formed will also give a race to art forum participants to always hone their knowledge.

\section{CONCLUSION}

Based on the results of research, the art learning society is conditioned as the main objective of organizing the program, which is to provide flexibility learning space for the development of students potential in the arts, so that everything related to the learning process of art forums is what supports the creation of active and independent art learning communities. High involvement and dedication by parties around art forum participants in helping art forum 
participants understand the importance of the learning process and realize their learning needs. Students with awareness of their learning needs can maximize the learning process and learning outcomes so that they can be useful for their life.

Internet literacy is a way to realize the art learning community. The internet as a learning resource provides flexibility and also freedom in access so that it can facilitate the diversity of art potentials developed. Easy internet access must be accompanied by the ability of art forum participants to sort, understand, evaluate all information obtained. Thus, the interests and potential of art forum participants can be maximally developed and able to aim at learning activities so that art forum participants can become personal learners who are aware of their learning needs and active in meeting their learning needs.

\section{REFERENCES}

[1] M. Septiani, "Pengalaman Pusat Kegiatan Belajar Masyarakat ( PKBM ) dalam Memfasilitasi Masyarakat Belajar Sepanjang Hayat,” J. Ilm. Visi PPTK Paudni, vol. 10, no. 2, pp. 67-76, 2015.

[2] N. Novitasari, E. S. Redjeki, and Z. Nasution, "Strategi Membangun Masyarakat Gemar Belajar," J. Pendidik. Teor. Penelitian, dan Pengemb., vol. 3, no. 2, pp. 267-270, 2018.

[3] S. A. Kuntoro, "Pengembangan Masyarakat Belajar dalam Kerangka Pembangunan," Cakrawala Pendidik., vol. 16, no. 1, pp. 43-58, 1997.

[4] M. B. Miles, A. M. Huberman, and J. Saldana, Qualitative Data Analysis. Thousand Oak, CA: Sage Publications, 2014.

[5] R. H. Puspita and D. Rohedi, "The Impact of Internet Use for Students," IOP Conf. Ser. Mater. Sci. Eng., vol. 306, no. 1, pp. 1-7, 2018.

[6] I. E. Mulyaningsih, "Pengaruh Interaksi Sosial Keluarga, Motivasi Belajar, dan Kemandirian Belajar terhadap Prestasi Belajar," J. Pendidik. dan Kebud., vol. 20, no. 4, pp. 441-451, 2014.

[7] K. C. Setiawan, "Pengaruh Motivasi Kerja Terhadap Kinerja Karyawan Level Pelaksana Di Divisi Operasi Pt. Pusri Palembang," PSIKIS-Jurnal Psikol. Islam., vol. 1, no. 2, pp. 43-53, 2015.

[8] M. M. Choiri, "Upaya Pemanfaatan Lingkungan Sekitar sebagai Sumber Belajar Anak," J. Refleks. Edukatika, vol. 8, no. 1, pp. 89-98, 2017.

[9] A. Rifa'i, "Model Pengelolaan Program Pendidikan," J. Ilmu Pendidik., vol. 19, no. 1, pp. 120-127, 2013. 